\title{
DESKRIPSI PROSES BERPIKIR SISWA KELAS VIII SMP PADA SOAL PISA LITERASI MATEMATIKA
}

\author{
Theresia Kartika Candra Dewi ${ }^{1}$, Helti Lygia Mampouw ${ }^{2}$ \\ ${ }^{1}$ Program Studi Pendidikan Matematika, Universitas Kristen Satya Wacana Salatiga, 202014079@student.uksw.edu \\ ${ }^{2}$ Program Studi Pendidikan Matematika, Universitas Kristen Satya Wacana Salatiga, helti.mampouw@staff.uksw.edu
}

\begin{abstract}
INFO ARTIKEL
Riwayat Artikel:

Diterima: 02-03-2018

Disetujui: 18-04-2018

\section{Kata Kunci:}

Proses berpikir

Literasi matematika

Soal PISA

\section{ABSTRAK}

Abstrak: Penelitian ini bertujuan untuk mendeskripsikan proses berpikir siswa kelas VIII SMP pada soal PISA literasi matematika. Jenis penelitian ini adalah deskriptif kualitatif. Instrumen utama dalam penelitian ini adalah peneliti sendiri, dibantu lembar tes dan pedoman wawancara. Teknik analisis data yang digunakan adalah model Miles dan Huberman. Data yang dianalisis adalah proses berpikir siswa baik pada langkah pembentukan pengertian, pembentukan pendapat, dan pembentukan kesimpulan. Subjek terpilih adalah tiga siswa kelas VIII SMP Negeri 1 Salatiga. Hasil penelitian menunjukkan bahwa pada soal nomer 1,2, dan 3, ketiga subjek mampu menunjukkan langkah proses berpikir baik pada langkah pembentukan pengertian, pembentukan pendapat, dan pembentukan kesimpulan. Pada soal nomer 4 subjek INA dan subjek PSP menunjukkan ketiga langkah proses berpikir, sementara subjek IFP mengalami kesulitan pada langkah pembentukan pendapat dan pembentukan kesimpulan.
\end{abstract}

\begin{abstract}
This research aims to describe the thinking procces of student in grade VIII Junior High School in mathematics literacy of PISA's problems. The type of this research is descriptive qualitative. The main instrument in this study is the researchers themselves, assisted test and interview guides. Data analysis techinique that be used is Miles and Huberman model. Data analyzed is the students thinking procces both in the step of forming meaning, forming opinion, and forming conclution. The selected subject is three students in grade VIII in SMP N 1 Salatiga. The result showed that in the number 1,2, and 3, all of the subjects could show the steps of thinking procces both the forming meaning, forming opinion, and forming conclution. In number 4, subject INA and PSP could show the three steps of thinking proccces, while subject IFP had a difficulty in the forming opinion and forming conclution steps.
\end{abstract}

\section{A. LATAR BELAKANG}

PISA (Programme for International Student Assessment) adalah survei internasional yang dilaksanakan secara reguler sekali dalam tiga tahun sejak tahun 2000 untuk mengetahui literasi siswa usia 15 tahun dalam matematika (mathematics literacy), sains (science literacy), dan membaca (reading literacy). Fokus PISA adalah literasi yang menekankan pada keterampilan dan kompetensi siswa yang diperoleh dari sekolah dan dapat digunakan dalam kehidupan seharihari (OECD, 2009:9). Hasil survei siswa Indonesia dalam berbagai literasi di PISA sangat rendah, salah satu yang memprihatinkan adalah literasi matematika. Hal ini dibuktikan dalam hasil survei PISA (Program for Internetional Student Assessment) tahun 2012 dimana skor matematika Indonesia berada pada peringkat 64 dari 65 negara (OECD, 2014:5).

Salah satu sebab rendahnya hasil survei literasi matematika disebabkan oleh orientasi pembelajaran matematika di sekolah yang salah. Pengajaran matematika di sekolah lebih berorientasi pada "matematika sebagai produk berpikir" dan kurang memberi perhatian pada proses berpikir siswa (Isroil, Budayada, \& Masriyah, 2017:93). Lebih lanjut, Marpaung (dalam Isroil, 2017:93) menjelaskan bahwa tugas pokok pengajaran matematika di sekolah adalah mengetahui proses berpikir siswa dalam mempelajari matematika dan bagaimana pengetahuan matematika itu diinterpretasikan dalam pikiran. Maka dapat disimpulkan bahwa penting bagi guru mengetahui proses berpikir siswa dalam mempelajari matematika agar pembelajaran matematika menjadi lebih baik dan efektif untuk meningkatkan literasi matematika siswa.

Sebelum membahas mengenai proses berpikir, kita harus terlebih dahulu mengerti mengenai apa itu berpikir. Berpikir adalah memanipulasi dan mengubah informasi dalam memori seperti membentuk konsep, alasan, berpikir kritis, membuat keputusan, berpikir kreatif, dan memecahkan masalah (Santrock, 2014:9). Berpikir merupakan proses dinamis yang dapat kita ketahui proses dan jalannya. Menurut Suryabrata (1998:54) proses berpikir pada pokoknya terdapat tiga langkah yaitu (1) pembentukan pengertian, 
pembentukan pendapat, dan (3) pembentukan kesimpulan.

Proses pembentukan pengertian adalah ketika siswa mampu memahami pengertian-pengertian atau informasi yang ada di dalam matematika. Proses pembentukan pengertian meliputi siswa mengetahui pengertian-pengertian mana yang sama/ sejenis, ciri-ciri apa saja yang selalu ada atau tidak ada, dan dapat melakukan proses abstraksi (menyimpan informasi yang dianggap perlu dan membuang yang tidak perlu). Selanjutnya proses yang kedua adalah pembentukan pendapat. Proses pembentukan pendapat adalah proses dimana siswa mampu menghubungkan pengertian satu dengan yang lainnya. Lalu yang terakhir, proses pembentukan kesimpulan adalah proses dimana siswa mampu menyimpulkan melalui pendapat-pendapat apa yang menjadi tujuan siswa.

Berdasarkan hal tersebut akan dilakukan penelitian untuk mendeskripsikan proses berpikir siswa dalam mengerjakan soal PISA literasi matematika. Tujuan dari penelitian ini adalah untuk mendeskripsikan proses berpikir siswa kelas VIII SMP dalam mengerjakan soal PISA literasi matematika.

\section{B. METODE PENELITIAN}

Penelitian ini adalah penelitian deskriptif kualitatif. Penelitian ini mendiskripsikan proses berpikir dalam mengerjakan soal PISA pada siswa kelas VIII SMP Negeri 1 Salatiga. Penelitian ini dilakukan pada bulan Januari 2018 - Maret 2018.

Subjek dalam penelitian ini adalah siswa kelas VIII SMP Negeri 1 Salatiga, yaitu siswa berkemampuan tinggi. Alasan peneliti memilih siswa berkemampuan tinggi agar siswa mampu menjelaskan dan menunjukkan proses berpikirnya dengan runtut. Teknik pengambilan subjek menggunakan teknik purposive sampling, dimana subjek dipilih berdasarkan kriteria tertentu. Subjek dalam penelitian ini adalah 3 subjek dari kelas VIII SMP Negeri 1 Salatiga. Ketiga subjek dipilih dengan kategori siswa berkemampuan tinggi dilihat berdasarkan hasil nilai murni Tes Akhir Semester Ganjil tahun ajaran 2017/2018 dimana ketiga subjek mendapatkan nilai 100. Proses berpikir terdiri dari 3 langkah yaitu pembentukan pengertian, pembentukan pendapat dan pembentukan kesimpulan.

Instrumen utama dalam penelitian ini adalah peneliti sendiri, dengan soal tes dan pedoman wawancara. Soal tes yang diberikan berupa soal PISA literasi matematika sebanyak 4 soal. Data yang akan dikumpulkan dalam penelitian ini berupa tulisan dan kata-kata yang menunjukkan proses berpikir siswa dalam menyelesaikan soal PISA. Data yang didapatkan meliputi lembar hasil jawaban siswa pada tes yang diberikan oleh peneliti serta rekaman wawancara subjek yang telah ditulis dalam sebuah transkrip.

\section{HASIL DAN PEMBAHASAN}

Hasil penelitian berupa deskripsi proses berpikir siswa dalam menyelesaikan soal PISA. Berdasarkan hasil pekerjaan dari 3 siswa kelas VIII SMP N 1 Salatiga, peneliti mendeskripsikan proses berpikir masing-masing subjek dari setiap soal yang diberikan.

1. Deskripsi Proses Berpikir Subjek Pada Soal Nomer 1

Soal nomer 1 adalah sebagai berikut:

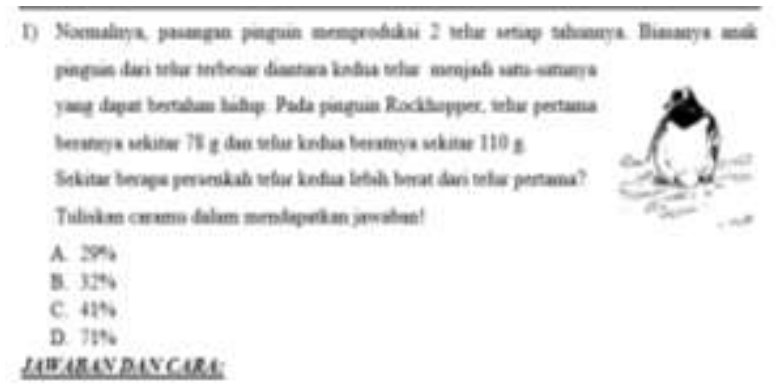

Gambar 1. Soal nomer 1 soal PISA Literasi Matematika

Soal nomer 1 memiliki beberapa karakteristik dalam proses berpikir yaitu:

\section{Pembentukan pengertian}

a. Subjek mampu mengerti mengenai informasi apa saja yang didapatkan dari soal ini yaitu pinguin memproduksi 2 telur setiap tahun, pinguin yang berasal dari telur terbesar menjadi satu-satunya yang hidup, pinguin memiliki 2 telur, telur pertama seberat 78 gram, telur kedua seberat 110 gram, dan persentase telur kedua lebih berat dari telur pertama. Keenam informasi tersebut merupakan pengertianpengertian yang harus dimiliki subjek.

b. Subjek mampu mengerti mengenai kesamaan dan perbedaan antar pengertian yang didapat yaitu pengertian yang memiliki kesamaan adalah telur pertama dan telur kedua sama-sama telur pinguin (sehingga melalui kesamaan pengertian ini dapat dilakukan pembentukan pendapat).

c. Subjek mampu melakukan proses abstraksi dimana ada beberapa pengertian yang penting untuk diketahui/digunakan untuk menyelesaikan soal yaitu pengertian mengenai berat telur pertama dan kedua serta persentase berat telur kedua lebih berat dari telur pertama. Lalu pengertian yang tidak penting untuk diketahui/tidak digunakan untuk menyelesaikan soal yaitu pengertian-pengertian lainnya yang telah dijelaskan di poin pertama.

\section{Pembentukan pendapat}

a. Subjek mampu menghubungkan pengertianpengertian menjadi pendapat yaitu melalui berat telur pertama 78 gram (pengertian 1) dan berat telur kedua 110 gram (pengertian 2) dapat dibuat pendapat dimana hubungan kedua pengertian ini adalah selisih dari kedua berat telur dapat membantu dalam mencari 
persentase berat telur kedua lebih berat dari telur pertama (pengertian 3). Subjek diperbolehkan untuk mengerjakan dengan berbagai cara, salah satunya adalah menggunakan rumus $\frac{\text { (berat telur kedua -berat telur pertama })}{\text { berat telur kedua }} \times 100 \%$.

\section{Pembentukan kesimpulan}

a. Subjek menunjukkan hasil kesimpulan berupa hasil akhir dari soal tersebut. Hasil akhir dari soal nomer 1 adalah 41\%. Salah satu cara mencarinya adalah $\frac{(110-78)}{78} \times 100 \%=\frac{32}{78} \times$ $100 \%=41,025 \% \approx 41$

1) Subjek INA

Hasil pengerjaan soal no 1 oleh subjek INA adalah sebagai berikut:

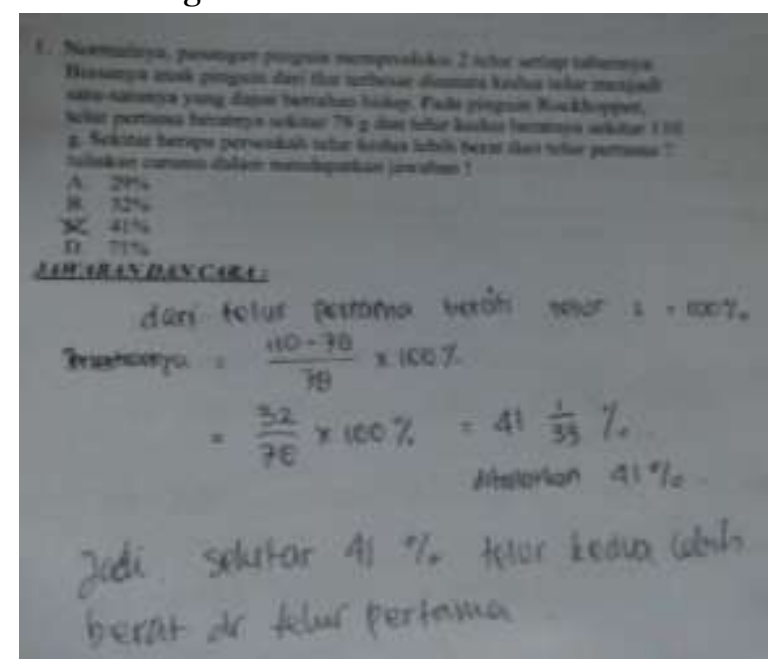

Gambar 2. Hasil pekerjaan nomer 1 Subjek INA

Subjek INA dalam mengerjakan nomer 1 sudah mampu menunjukkan informasi-informasi apa sajakah yang didapat didalam soal. Subjek juga sudah mampu mengabstraksi informasi manakah yang berguna untuk menyelesaikan soal atau tidak. Proses abstraksi dapat dilihat pada hasil pekerjaan subjek, dimana tidak semua informasi yang ada didalam soal digunakan oleh subjek.

Subjek INA juga mampu menunjukkan hubungan antara informasi satu dengan informasi yang lainnya. Subjek INA dalam wawancara mengatakan bahwa melalui informasi berat telur 1 dan berat telur kedua maka dapat dihitung perbandingan dengan menghubungkan kedua informasi tersebut. Subjek INA dalam mencari perbandingan telur kedua dibandingkan telur pertama memisalkan telur pertama menjadi $100 \%$. Maka subjek INA dapat membuat pendapat dari informasi-informasi yang ada yaitu presentase telur kedua lebih berat dari telur pertama dengan rumus : $\frac{\text { (berat telur kedua-berat telur pertama) }}{\text { berat telur kedua }} \times 100 \%$

Selanjutnya, subjek INA mampu menunjukkan langkah selanjutnya dari proses berpikir yaitu pembentukan kesimpulan. Subjek INA memberikan kesimpulan atas penyelesaian soal tersebut. Kesimpulan dari subjek INA adalah persentase telur kedua lebih berat dari telur pertama sekitar $41 \%$.

2) Subjek PSP

Hasil pengerjaan soal no 1 oleh subjek PSP adalah sebagai berikut:

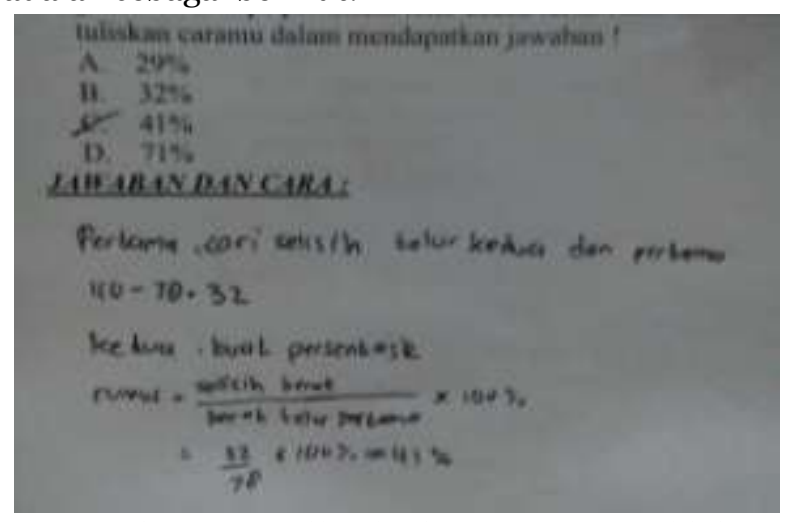

Gambar 3. Hasil pekerjaan nomer 1 Subjek PSP

Subjek PSP dalam mengerjakan soal nomer 1 sudah mampu menjelaskan informasi apa saja yang subjek dapatkan pada soal tersebut. Subjek PSP juga mampu menjelaskan abstraksi yang ia lakukan untuk memisahkan informasi yang penting dan tidak penting. Langkah pembentukan informasi dapat dilihat melalui hasil pekerjaan subjek PSP, dimana ia tidak menggunakan informasi yang ia tidak butuhkan dalam menyelesaikan soal (abstraksi) dan mampu memahami pengertian-pengertian yang ada dengan tepat.

Kemudian subjek PSP mampu menunjukkan langkah selanjutnya yaitu pembentukan pendapat. Subjek PSP menunjukkan bahwa hubungan dari beberapa informasi yang telah disebutkan pada langkah pembentukan informasi dapat membantunya untuk mengerjakan masalah yang tersedia. Melalui wawancara subjek PSP mengatakan bahwa hubungan antara kedua berat telur yang berbeda dapat membantunya dalam mengetahui presentase berat telur kedua terhadap telur pertama. Subjek PSP mengatakan bahwa dengan menggunakan hubungan berat kedua telur ia dapat memasukkannya dalam rumus yang ia pelajari sewaktu SD dan dapat mendapatkan jawaban atas permasalahan yang tersedia. Langkah pembentukan pendapat dapat dilihat pula dalam hasil pekerjaan subjek PSP dimana subjek mampu menghubungkan beberapa pengertian untuk mengerjakan soal dan mendapatkan jawaban akhirya.

Langkah selanjutnya yaitu pembentukan kesimpulan. Subjek PSP menunjukkan hasil kesimpulannya berupa jawaban akhir soal yaitu $41 \%$ (dengan memilih pilihan C. $41 \%$ ). 
3) Subjek IFP

Hasil pengerjaan soal no 1 oleh subjek IFP adalah sebagai berikut:

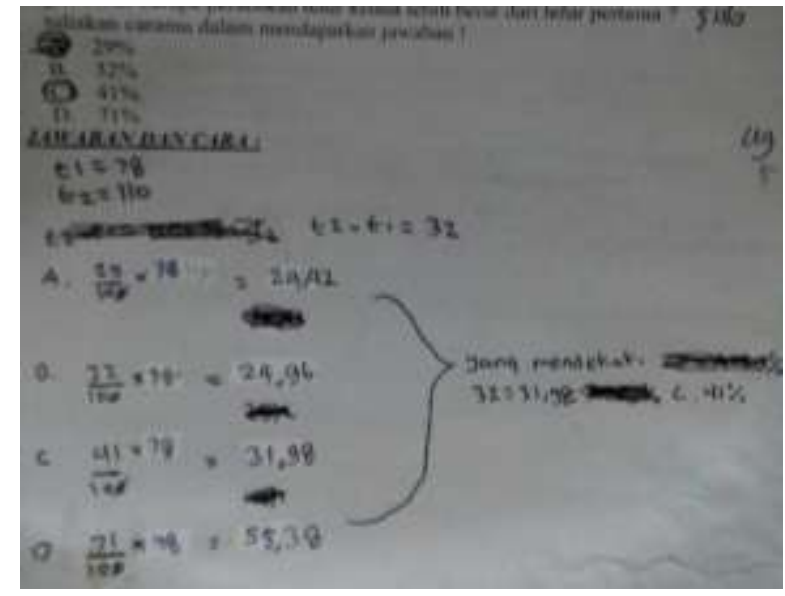

Gambar 4. Hasil pekerjaan nomer 1 subjek IFP

Subjek IFP dalam mengerjakan soal nomer 1 telah menunjukkan langkah pembentukan pengertian yaitu ditunjukkan melalui wawancara dan hasil pekerjaan subjek. Subjek IFP menjelaskan informasi apa saja yang ia dapatkan dan abstraksi dari informasi-informasi yang ia dapatkan. Langkah pembentukan pengertian dapat ditunjukkan melalui hasil pekerjaan subjek IFP dimana tidak semua informasi ia gunakan dalam mengerjakan soal (abstraksi) dan informasi yang ia dapatkan kemudian digunakan dalam proses penyelesaian masalah.

Subjek IFP selanjutnya menunjukkan langkah berikutnya yaitu pembentukan pendapat. Subjek IFP menjelaskan melalui wawancara dan hasil pekerjaannya bahwa ia mampu menghubungkan informasi satu dengan informasi lainnya seperti melalui informasi berat kedua telur dapat dicari persentasenya. Subjek IFP menggunakan carapenyelesaian yaitu melalui setiap pilihan ganda ia menghitung persentase yang mendekati selisih kedua telur. Langkah pembentukan pendapat ditunjukkan dalam hasil pekerjaan subjek IFP dimana setiap pengertian ia hubungkan untuk membentuk pendapat yang akhirnya membawa subjek untuk menemukan jawaban soalnya.

Kemudian, subjek IFP menunjukkan langkah pembentukan kesimpulan melalui wawancara dan hasil pekerjaan. Subjek IFP menghubungkan pendapat-pendapatnya dan memberikan kesimpulan bahwa persentase telur kedua dari telur pertama adalah $41 \%$ karena ketika $41 \%$ dikali dengan 78 (berat telur pertama) hasilnya sama dengan 31,98 dimana 31,98 mendekati angka 32 yaitu selisih dari kedua telur.

\section{Deskripsi proses berpikir subjek pada soal nomer 2}

Soal nomer 2 adalah sebagai berikut:
2) Jean bertasya-anys opakah jumlah koloni pinguin akan berubah dalam beteraps tahur kodepua

Untuk mesastikan hal orsetbut, dia menteant aumasi berikut

- Pads awal tatar koloei terdiri dasi 10,000 pingrain (5,000 paangan)

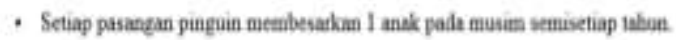

- Pada alhir talun 2095 dari semus pingrin (devasa dan anak-mak) akan mati

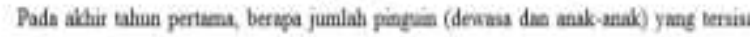
poda kolon?? Taliskas carams untuk wendapukan jawabas tervebut! JAWABANDANCARA:

\section{Gambar 5. Soal nomer 2 soal PISA Literasi} Matematika

Soal nomer 2 memiliki beberapa karakteristik dalam proses berpikir yaitu:

\section{Pembentukan pengertian}

a. Subjek mampu mengerti mengenai informasiinformasi apa saja yang didapatkan dari soal ini yaitu pada awal tahun terdapat 10.000 pinguin/ 5000 pasang pinguin, setiap pasang pinguin membesarkan 1 anak setiap tahun, pada akhir tahun 20\% dari total semua populasi pinguin mati, dan jumlah pinguin di dalam koloni pada akhir tahun. Keempat informasi tersebut adalah pengertian-pengertian yang harus dimiliki subjek.

b. Subjek mampu mengabstraksi pengertianpengertian yang ada, dimana pada soal nomer 2 semua informasi yang ada adalah penting sehingga tidak perlu dibuang saat menyelesaikan soal.

\section{Pembentukan pendapat}

a. Subjek mampu menghubungkan pengertianpengertian yang ada menjadi pendapat yaitu: (a) pada awal tahun terdapat 10.000 pinguin atau 5.000 pasang pinguin (pengertian 1) dan setiap pasang membesarkan 1 anak setiap tahun (pengertian 2) maka dapat dibuat pendapat bahwa terdapat 5.000 anak pinguin yang dibesarkan setiap tahunnya (pendapat 1); (b) jika pada awal tahun terdapat 10.000 pinguin (pengertian 1) dan terdapat 5.00o anak yang dibesarkan setiap tahun (pendapat 1), maka 20\% populasi pinguin yang mati (pengertian3) adalah $\frac{20}{100} \times(10.000+$ $5.000=3.000$ pinguin (pendapat 2); (c) jika subjek telah membentuk pendapat (2) maka subjek dapat mengetahui jumlah pinguin yang hidup pada tahun pertama (pengertian 4). Subjek diperbolehkan untuk menggunakan berbagai cara, salah satunya adalah jumlah pinguin awal pendapat 2.

Pembentukan kesimpulan

a. Subjek menunjukkan hasil kesimpulan berupa hasil akhir dari soal tersebut. Hasil akhir dari soal nomer 2 adalah 12.000 pinguin. Salah satu cara mencarinya adalah 15.000 pinguin -3.000 pinguin $=12.000$ pinguin.

1) Subjek INA 
Hasil pengerjaan soal no 2 oleh subjek INA adalah sebagai berikut:

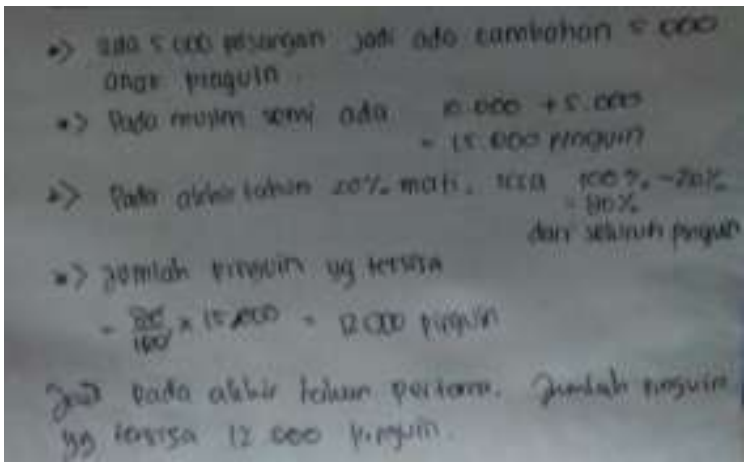

Gambar 6. Hasil pekerjaan nomer 2 subjek INA

Subjek INA dalam mengerjakan soal nomer 2 sudah mampu menjelaskan informasi apa saja yang ia dapatkan. Informasi-informasi tersebut disampaikan kepada peneliti melalui wawancara diantaranya adalah penjelasan dari setiap asumsiasumsi yang ada. Subjek INA juga menyampaikan mengenai abstraksi informasi-informasi yang ada. Subjek INA dalam mengabstraksi dapat dilihat melalui hasil pekerjaannya bahwa tidak ada informasi yang ia hilangkan atau dianggap tidak penting karena dalam mengerjakan soal tersebut subjek INA menggunakan semua informasi yang ada.

Selanjutnya, subjek INA mampu menunjukkan langkah selanjutnya yaitu pembentukan pendapat yang ditunjukkan melalui hasil pekerjaan dan wawancara. Melalui hasil pekerjaan dan wawancara, subjek menunjukkan bahwa pengertian-pengertian yang telah ia dapatkan melalui setiap asumsi ia hubungkan sehingga ia dapat mendapatkan jawaban dari permasalahan yang ada. Melalui hasil pekerjaan subjek, dapat dilihat bahwa setiap asumsi ia hubungkan untuk mencari jawaban akhir sehingga dapat disimpulkan bahwa subjek sudah mampu membentuk pendapat dimana setiap pengertian-pengertian dapat saling dihubungkan oleh subjek INA.

Subjek INA kemudian menunjukkan langkah selanjutnya yaitu pembentukan kesimpulan melalui hasil pekerjaannya. Subjek INA memberikan kesimpulan dari pendapat-pendapat yang telah ia temukan. Kesimpulan yang dibentuk oleh subjek INA adalah jawaban akhir dari soal tersebut yaitu 12.000 pinguin.

2) Subjek PSP

Hasil pengerjaan soal no 2 oleh subjek PSP adalah sebagai berikut:

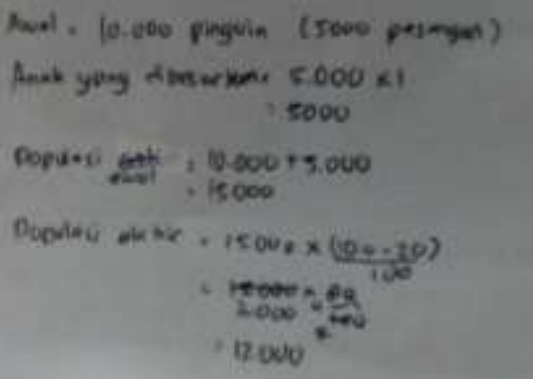

Gambar 7. Hasil pekerjaan nomer 2 subjek PSP

Subjek PSP dalam mengerjakan soal nomer 2 telah menunjukkan langkah pembentukan pengertian. Subjek PSP melalui wawancara dan hasil pekerjaan mengungkapkan pengertianpengertian apa saja yang ia dapatkan dan dapat memberitahu peneliti mengenai proses abstraksinya. Melalui hasil pekerjaannya, subjek PSP menunjukkan proses abstraksi dimana semua pengertian ia pakai dan tidak ada pengertian yang ia buang atau tidak digunakan dalam proses penyelesaian soal.

Kemudian, subjek PSP menunjukkan langkah selanjutnya yaitu pembentukan pendapat melalui wawancara dan hasil pekerjaannya. Melalui hasil pekerjaannya, subjek PSP menunjukkan hubungan antar pengertian yang ia dapatkan sehingga ia memperoleh jawaban dari permasalahan tersebut. Langkah pembentukan pendapat dapat dilihat dari hasil pekerjaan subjek PSP dimana setiap penghubungan beberapa informasi menghasilkan pendapat untuk kemudian digunakan untuk mengerjakan soal. Pendapat yang terbentuk kemudian dihubungkan dengan pengertian selanjutnya untuk menyelesaikan soal hingga menemukan jawaban akhirnya.

Selanjutnya dalam langkah pembentukan kesimpulan, subjek PSP menunjukkannya dalam wawancara dan hasil pekerjaan. Subjek PSP menyampaikan bahwa melalui pendapat-pendapat yang ia dapatkan, ia mengambil kesimpulan bahwa jumlah populasi pinguin pada akhir tahun pertama adalah 12.000 pinguin (dapat dilihat pula dalam hasil pekerjaan).

3) Subjek IFP

Hasil pengerjaan soal no 2 oleh subjek IFP adalah sebagai berikut:

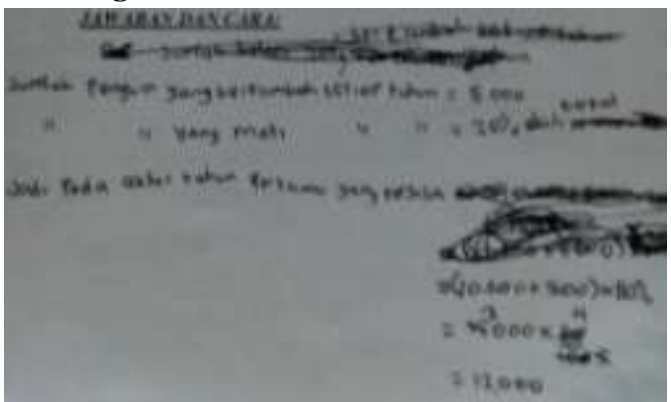

Gambar 8. Hasil pekerjaan nomer 2 subjek IFP 
Subjek IFP dalam mengerjakan soal nomer 2 dapat menunjukkan langkah pembentukan pengertian. Subjek IFP memberitahu peneliti mengenai informasi apa saja yang ia dapatkan melalui soal tersebut dalam wawancara dan hasil pekerjaan subjek. Pengertian-pengertian yang diabstraksi dapat ditunjukkan melalui hasil pekerjaan subjek dimana semua pengertian digunakan oleh subjek (tidak ada yang dibuang) untuk mengerjakan soal tersebut.

Subjek IFP dalam langkah pembentukan pendapat menunjukkannya melalui wawancara dan hasil pekerjaan. Subjek IFP mampu menghubungkan pengertian-pengertian yang ia dapat sehingga dapat mengerjakan permasalahan yang tersedia. Langkah pembentukan pendapat dapat dilihat dari hasil pekerjaan subjek IFP dimana pengertian-pengertian dihubungkan sehingga membentuk pendapat dan pendapat tersebut dihubungkan pada pengertian (asumsi) selanjutnya sebagai langkah dalam menemukan hasil akhir soal tersebut.

Subjek IFP selanjutnya masuk dalam langkah pembentukan kesimpulan. Subjek IFP melalui wawancara menunjukkan kesimpulannya berdasarkan pendapat-pendapat yang ia dapatkan. Kesimpulan subjek IFP dalam soal nomer 2 ini adalah bahwa jumlah populasi pinguin dalam koloni tersebut pada akhir tahun adalah 12.000 pinguin (ditunjukkan melalui hasil pekerjaan subjek).

\section{Deskripsi proses berpikir subjek pada soal} nomer 3

Soal nomer 3 adalah sebagai berikut:

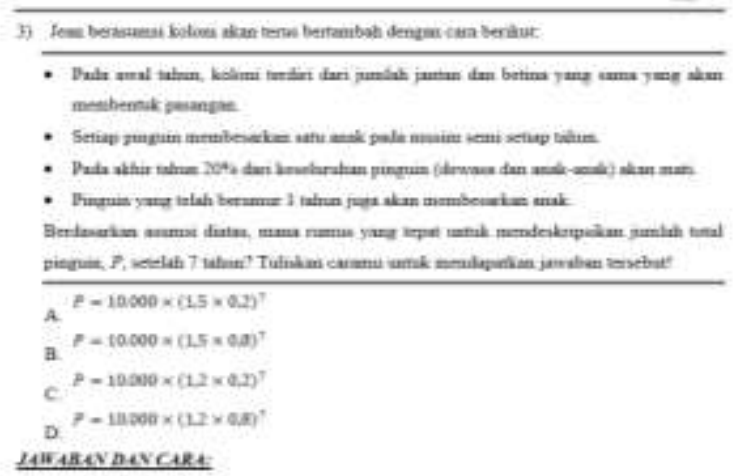

Gambar 9. Soal nomer 3 soal PISA Literasi Matematika

Soal nomer 3 memiliki beberapa karakteristik dalam proses berpikir yaitu:

\section{Pembentukan pengertian}

a. Subjek mampu mengerti mengenai informasi apa saja yang didapatkan dari soal ini yaitu pada awal tahun jumlah pinguin jantan dan betina sama dan membentuk pasangan, setiap pasang pinguin membesarkan anak setiap tahun, pada akhir tahun 20\% dari total populasi akan mati, pinguin yang telah berumur 1 tahun sudah bisa membesarkan anak, dan rumus jumlah pinguin (P) setelah 7 tahun. Kelima informasi tersebut adalah pengertian-pengertian yang harus dimiliki subjek.

b. Subjek mampu mengabstraksi pengertianpengertian yang ada, dimana pada soal nomer 3 semua informasi yang ada adalah penting sehingga tidak perlu dibuang saat menyelesaikan soal.

\section{Pembentukan pendapat}

a. Subjek mampu menghubungkan pengertianpengertian yang ada menjadi pendapat yaitu: (a) pada awal tahun jumlah pinguin jantan dan betina sama dan membentuk pasangan (pengertian 1) serta setiap pasang membesarkan 1 anak setiap tahun (pengertian 2) dapat dibentuk sebuah pendapat dimana misalkan ada $a$ pasang pinguin maka akan ada $\frac{1}{2} a$ anak yang dibesarkan (pendapat 1); (b) pada akhir tahun 20\% dari total populasi mati (pengertian 3) maka hanya 80\% dari total populasi yang hidup sehingga dari total $\left(\begin{array}{ll}1 / 2 & a+a\end{array}\right)$ pinguin tersisa populasi $\frac{80}{100} \times$ $\frac{3}{2} a$ (pendapat 2); (c) jika pinguin yang telah berumur 1 tahun dapat membesarkan anak (pengertian 4) maka pada tahun selanjutnya siklus akan terulang karena pinguin termuda akan mengulang siklus melahirkan dan mati (pendapat 3)

\section{Pembentukan kesimpulan}

a. Subjek menunjukkan hasil kesimpulan berupa hasil akhir dari soal tersebut. Hasil akhir dari soal tersebut adalah $\frac{3}{2} a \times 80 \%=1,5 \times 0,8$. Karena pada soal sebelumnya jumlah awal populasi adalah 10.000 maka siklus 1 tahun adalah $10.000 \times 1,5 \times 0,8$ maka siklus selama 7 tahun jika populasi awal tetap 10.000 adalah $P=10.000 \times$ $(1,5 \times 0,8)^{7}$

\section{1) Subjek INA}

Hasil pengerjaan soal nomer 3 oleh subjek INA adalah sebagai berikut:

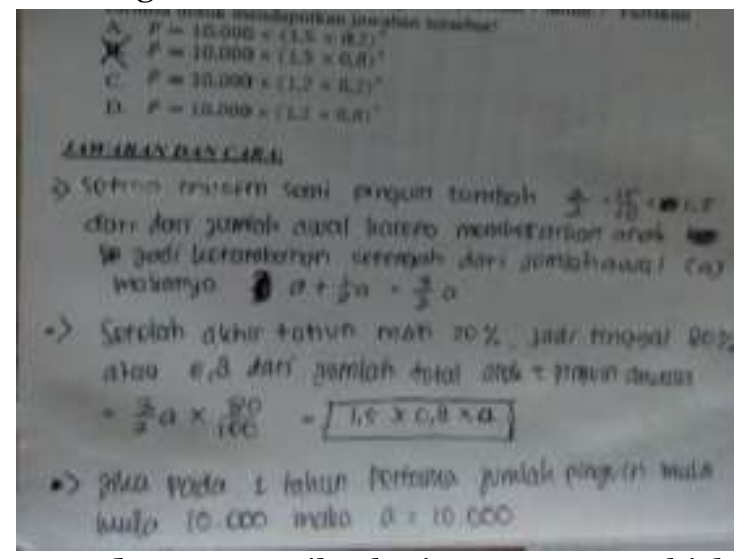

Gambar 10. Hasil pekerjaan nomer 3 subjek INA

Subjek INA dalam mengerjakan soal nomer 3 menunjukkan langkah pembentukan pengertian 
melalui wawancara dan hasil pekerjaan. Subjek INA melalui wawancara menunjukkan informasi apa sajakah yang ia dapatkan dari soal tersebut. Melalui hasil pekerjaan diatas, subjek INA sudah mampu melakukan abstraksi dimana semua informasi digunakan dan dianggap penting untuk menyelesaikan soal nomer 3 .

Subjek INA kemudian menunjukkan langkah pembentukan pendapat melalui wawancara dan hasil pekerjaannya. Melalui hasil pekerjaan berikut, subjek menghubungkan beberapa pengertian yang ia ketahui menjadi pendapat-pendapat yang membantu subjek INA dalam menyelesaikan permasalahan yang ada.Subjek INA dalam mengerjakan soal tersebut, satu per satu pengertian dihubungkan sehingga proses pembentukan pendapat dapat ditunjukkan. Setiap pendapat (hubungan tiap asumsi) dapat memberikan pendapat baru untuk dihubungkan pada asumsi selanjutnya sehingga hasil akhir dapat ditemukan.

Selanjutnya dalam langkah pembentukan kesimpulan, subjek INA menunjukkannya melalui wawancara dan hasil pekerjaannya. Subjek INA memberikan kesimpulan melalui hubungan antara pendapat-pendapat yang ia ketahui. Subjek INA memberikan kesimpulan bahwa jawaban dari permasalahan ini adalah B yaitu $P=10.000 \times$ $(1,5 \times 0,8)^{7}$. Subjek INA menambahkan pembuktian pada hasil pekerjaannya untuk memperkuat jawabannya, yaitu ketika rumus tersebut berlaku untuk 1 tahun maka jawabannya sama dengan jawaban soal nomer 2 yaitu 12.00o.

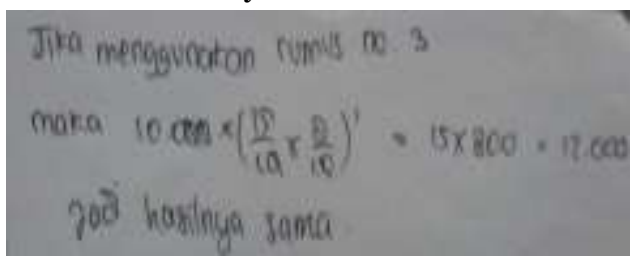

Gambar 11. Hasil pekerjaan nomer 3 Subjek INA dalam langkah pembentukan kesimpulan

2) Subjek PSP

Hasil pengerjaan soal no 3 oleh subjek PSP adalah sebagai berikut:

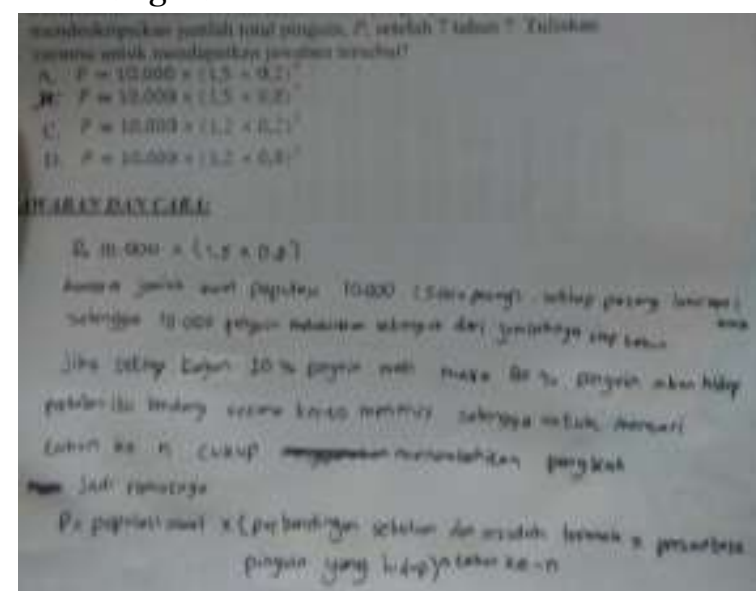

Gambar 12. Hasil pekerjaan nomer 3 subjek PSP
Subjek PSP dalam mengerjakan soal ketiga menunjukkan langkah pembentukan pengertian melalui hasil pekerjaan subjek. Melalui wawancara dan hasil pekerjaan, subjek PSP menunjukkan kepada peneliti mengenai informasi apa saja yang ia dapatkan telah ia tuliskan pada lembar jawab dan abstraksi dari setiap pengertian yang ia dapatkan yaitu bahwa subjek PSP menganggap semua informasi penting dalam membantunya menjawab permasalahan tersebut.

Subjek PSP kemudian menunjukkan langkah pembentukan pendapat melalui wawancara dan hasil pekerjaannya. Subjek melalui wawancara mengatakan bahwa ia menghubungkan berbagai pengertian yang ia dapatkan menjadi sebuah pendapat. Pendapat tersebut adalah sebuah rumus yang menjadi jawaban dari permasalahan tersebut. Rumus tersebut subjek PSP tuliskan dalam lembar jawabnya. Proses penggabungan pengertianpengertian menjadi pendapat tersebut ditunjukkan oleh subjek PSP sehingga dapat menemukan hasil akhir dari soal tersebut.

Subjek PSP kemudian menunjukkan langkah selanjutnya yaitu pembentukan kesimpulan. Melalui wawancara, subjek PSP menyimpulkan berdasarkan pendapat-pendapat yang ada bahwa kesimpulan dari soal tersebut adalah bahwa rumus yang tepat untuk mendeskripsikan jumlah total pinguin setelah 7 tahun adalah $P=10.000 \times(1,5 \times 0,8)^{7}$. Jawaban atau hasil pembentukan kesimpulan tersebut subjek tunjukkan juga melalui hasil pekerjaannya.

\section{3) Subjek IFP}

Hasil pengerjaan soal no 3 oleh subjek IFP adalah sebagai berikut:

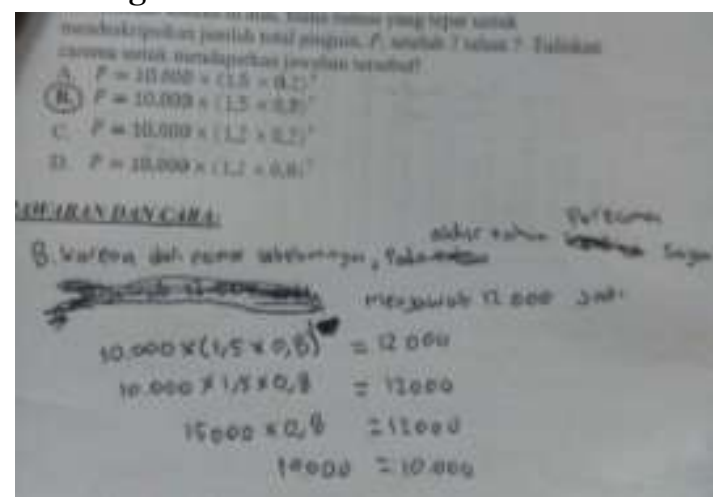

Gambar 13. Hasil pekerjaan nomer 3 subjek IFP

Subjek IFP dalam mengerjakan soal nomer 3 menunjukkan langkah pembentukan pengertian melalui wawancara dan hasil pekerjaan. Melalui wawancara tersebut, subjek IFP menunjukkan bahwa informasi apa saja yang ia dapat dari soal tersebut dan abstraksi dari informasi-informasi yang ada. Langkah pembentukan pengertian dapat dilihat melalui hasil pekerjaan subjek dimana setiap informasi tidak dibuang dan digunakan dalam mengerjakan soal tersebut (abstraksi). 
Subjek IFP kemudian menunjukkan langkah selanjutnya yaitu langkah pembentukan pendapat melalui wawancara dan hasil pekerjaannya. Melalui hasil pekerjaan dan wawancara, subjek IFP menghubungkan beberapa informasi yang ia dapat untuk menyelesaikan permasalahan tersebut. Subjek IFP mengatakan melalui wawancara bahwa ia menebak-nebak dari pilihan ganda yang ada dan memilih mencoba pilihan B. Kemudian membuktikannya dengan menggunakan jawaban nomer sebelumnya yaitu 12.000 pada tahun pertama. Sehingga ketika tahun pertama dan jumlah 12.000 disubstitusi kedalam rumus pilihan B memiliki hasil yang sama, maka jawaban tersebut benar. Pengertian-pengertian pada setiap asumsi yang dihubungkan menjadi pendapat dapat ditunjukkan melalui hasil pekerjaan subjek. Meskipun dalam pembentukan pendapat subjek tidak menunjukkan penghubungan antar pengertian dengan jelas (dalam hasil pekerjaan subjek), namun subjek mampu menyusun pendapat yang setengah jadi tersebut menjadi hasil akhir soal.

Subjek IFP kemudian menunjukkan langkah pembentukan kesimpulan melalui wawancara. Subjek IFP mengatakan bahwa kesimpulan yang ia dapatkan bahwa jawabannya adalah $B$ yaitu $P=10.000 \times$ $(1,5 \times 0,8)^{7}$ (ditunjukkan pada hasil pekerjaan subjek). Kesimpulan itu ia dapatkan setelah pendapat-pendapat yang ia ketahui ia hubungkan.

\section{Deskripsi proses berpikir subjek pada soal nomer 4}

Soal nomer 4 adalah sebagai berikut:

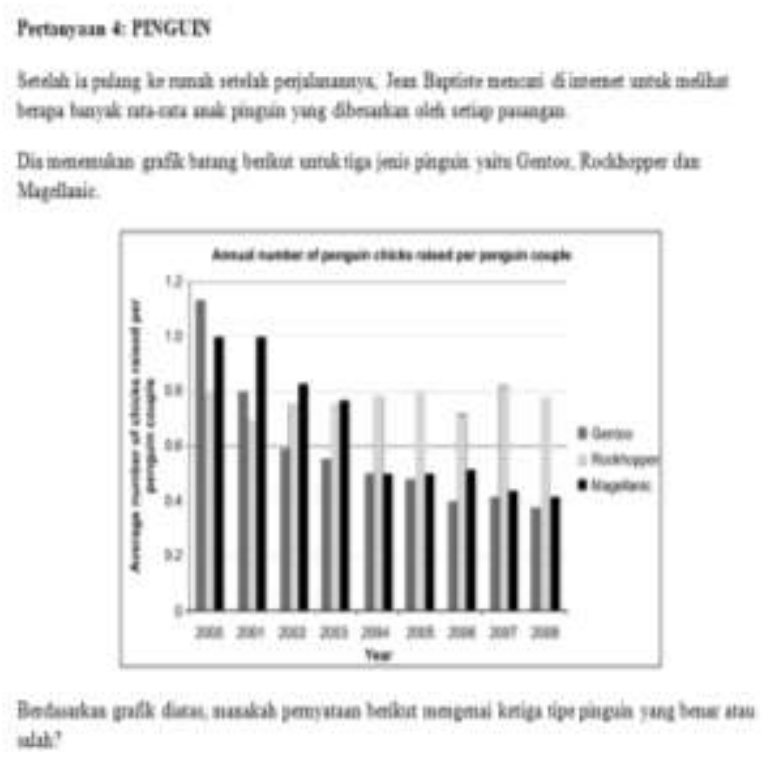

Gambar 14. Soal nomer 4 soal PISA Literasi Matematika (1)

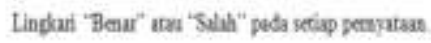

\begin{tabular}{|c|c|}
\hline Perayatasu & Perryatas iaibenar atas sabla? \\
\hline 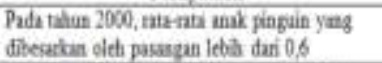 & Bent/Silit \\
\hline 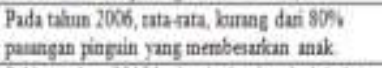 & Beur / 5 alah \\
\hline $\begin{array}{l}\text { Selstat tahn } 2015 \text { ketiga jetu pinguin iti alas } \\
\text { panah }\end{array}$ & Beast Salah \\
\hline 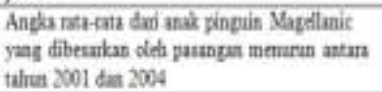 & Besar /Salah \\
\hline
\end{tabular}

Gambar 15. Soal nomer 4 soal PISA Literasi

Matematika (2)

Soal nomer 4 memiliki beberapa karakteristik dalam proses berpikir yaitu:

Pembentukan pengertian

a. Subjek mampu mengerti mengenai informasi apa saja yang didapatkan dari grafik soal ini yaitu pada tahun 2000 rata-rata anak pinguin yang dibesarkan oleh pinguin Gentoo sekitar 1,1; pinguin Rockhopper adalah 0,8 ; pinguin Magellanic adalah 1,0; pada tahun 2001 rata-rata anak pinguin yang dibesarkan oleh pinguin Gentoo adalah 0,8 ; pinguin Rockhopper adalah 0,7; pinguin Maggelanic adalah 1,0; pada tahun 2002 rata-rata anak pinguin yang dibesarkan oleh pinguin Gentoo sekitar 0,59; pinguin Rockhopper sekitar 0,77; pinguin Magellanic sekitar o,83; pada tahun 2003 rata-rata anak pinguin yang dibesarkan oleh pinguin Gentoo sekitar 0,57; pinguin Rockhopper sekitar 0,76; pinguin Magellanic sekitar 0,77; pada tahun 2004 ratarata anak pinguin yang dibesarkan pinguin Gentoo adalah 0,5; pinguin Rockhopper sekitar 0,79; pinguin Magellanic adalah 0,5; pada tahun 2005 rata-rata anak pinguin yang dibesarkan pinguin Gentoo sekitar 0,49; pinguin Rockhopper adalah 0,8; pinguin Magellanic 0,5; pada tahun 2006 rata-rata anak pinguin yang dibesarkan oleh pinguin Gentoo 0,4; pinguin Rockhopper adalah 0,7; pinguin Magellanic adalah 0,5 ; pada tahun 2007 rata-rata anak pinguin yang dibesarkan oleh pinguin Gentoo sekitar 0,43; pinguin Rockhopper sekitar 0,83; pinguin Magellanic sekitar 0,45; pada tahun 2008 rata-rata anak pinguin yang dibesarkan oleh pinguin Gentoo sekitar 0,39; pinguin Rockhopper sekitar 0,79; pinguin Magellanic sekitar 0,41. Pengertian yang harus diketahui pula oleh subjek adalah penyataanpernyataan yang harus dibuktikan benar-salahnya. Semua informasi tersebut adalah pengertianpengertian yang harus dimiliki subjek.

b. Subjek mampu mengabstraksi pengertianpengertian yang ada, dimana pada soal nomer 4 semua informasi yang ada adalah penting dan digunakan dalam menyelesaikan soal.

\section{Pembentukan pendapat}

a. Subjek mampu menghubungkan pengertianpengertian yang ada menjadi pendapat yaitu (a) pada tahun 2000, rata-rata anak pinguin yang 
dibesarkan oleh pasangan lebih dari o,6 (pengertian 1). Jika dilihat pada grafik rata-rata anak pinguin Gentoo, Rockhopper dan Magellanic semuanya lebih dari o,6 (pengertian 2) maka dapat disimpulkan bahwa pengertian 1 benar karena dibuktikan pada pengertian 2 (pendapat 1); (b) pada tahun 2006, rata-rata, kurang dari $80 \%$ pasangan pinguin yang membesarkan anak (pengertian 3). Jika dilihat pada grafik pada tahun 2006, ketiga jenis pinguin membesarkan anak rata-rata kurang dari o,8 atau 80\% (pengertian 4) maka dapat disimpulkan bahwa pengertian 3 benar karena dibuktikan pada pengertian 4 (pendapat 2); (c) sekitar tahun 2015 ketiga jenis pinguin ini akan punah (pengertian 5). Jika dilihat pada grafik, ketiga jenis pinguin memiliki ratarata yang naik turun setiap tahunnya, namun tidak pernah mendekati nilai o,2 hingga tahun 2008 (pengertian 6) maka subjek dapat memprediksi bahwa hingga tahun 2015 pinguin tidak akan punah seluruhnya atau setidaknya hanya 1 atau 2 jenis saja yang punah karena populasi pinguin Gentoo masih diatas o,6 (pendapat 3); (d) angka rata-rata dari anak pinguin Magellanic yang dibesarkan oleh pasangan menurun atara 2001 dan 2004 (pengertian 7). Jika dilihat dari tabel maka ratarata dari anak pinguin Magellanic yang dibesarkan menurun dari 1,0 ke 0,83 lalu 0,77 hingga 0,5 (pengertian 8) maka dapat disimpulkan bahwa pengertian 7 benar karena dibuktikan pada pengertian 8 (pendapat 4).

\section{Pembentukan kesimpulan}

a. Subjek menunjukkan hasil kesimpulan berupa hasil akhir dari soal tersebut. Hasil akhir dari soal tersebut adalah penyataan pertama benar, pernyataan kedua benar, pernyataan ketiga salah dan pernyataan keempat benar.

1) Subjek INA

Hasil pengerjaan soal nomer 4 oleh subjek INA adalah sebagai berikut:

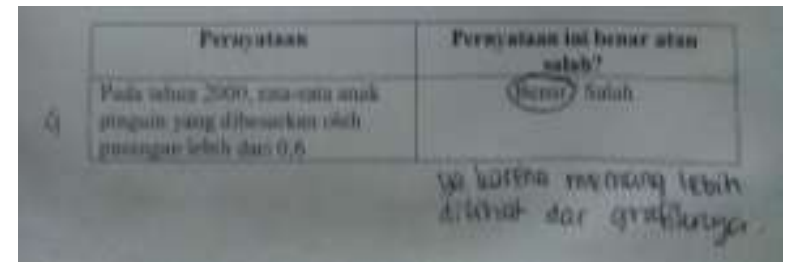

Gambar 16. Hasil pekerjaan nomer 4 Subjek INA (1)

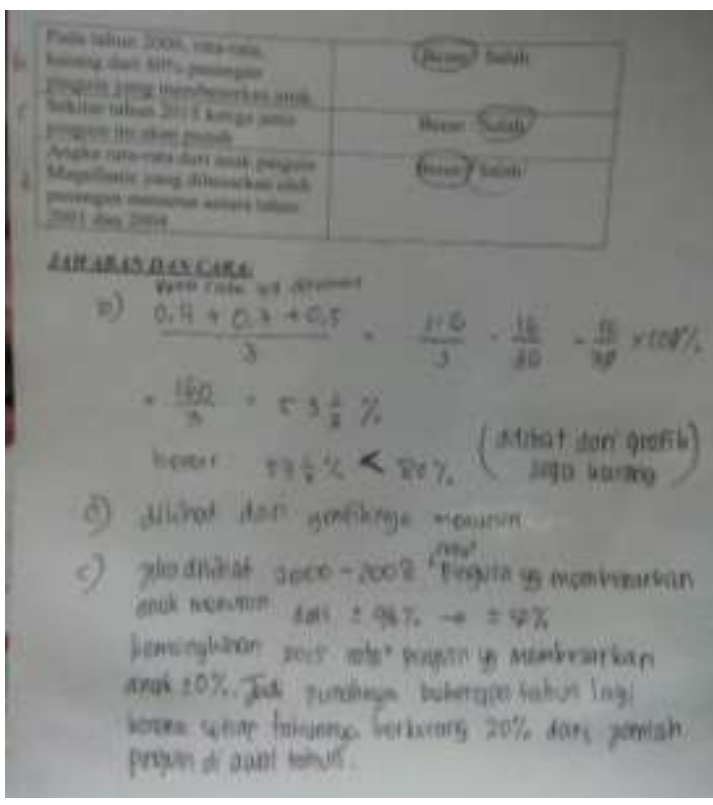

Gambar 17. Hasil pekerjaan nomer 4Subjek INA (2)

Subjek INA dalam mengerjakan soal nomer 4 sudah mampu menjelaskan informasi apa saja yang subjek dapatkan pada soal tersebut. Melalui wawancara dan hasil pekerjaan, subjek INA menunjukkan bahwa informasi yang ia dapatkan berasal dari grafik yang ada. Semua informasi didalam grafik penting sehingga tidak ada abstraksi dimana informasi dibuang karena tidak penting. Hal tersebut terlihat dalam hasil pekerjaan subjek INA, dimana pengertian-pengertian dalam soal dimasukkan ke dalam penyelesaian soal.

Kemudian subjek INA menunjukkan langkah selanjutnya yaitu pembentukan pendapat melalui hasil pekerjaan dan wawancara. Melalui wawancara, subjek INA mengatakan bahwa ia menghubungkan pengertian yang ia dapatkan untuk membantu subjek dalam menjawab pertanyaan benar/salah tersebut. Setiap informasi yang ada dihubungkan oleh subjek INA, sehingga dalam menentukan benar/salahnya pernyataan yang diberikan, subjek menggunakan bukan hanya 1 pengertian namun beberapa pengertian yang ia bandingkan dan hubungkan.

Subjek INA kemudian menjelaskan mengenai langkah selanjutnya yaitu pembentukan kesimpulan melalui wawancara. Subjek INA menjelaskan bahwa kesimpulan yang ia dapatkan adalah jawaban dari setiap soal yaitu berturut-turut benar, benar, salah, benar. Kesimpulan tersebut berdasarkan pendapatpendapat yang telah ia dapatkan pada langkah sebelumnya.

2) Subjek PSP

Hasil pengerjaan soal no 4 oleh subjek PSP adalah sebagai berikut: 


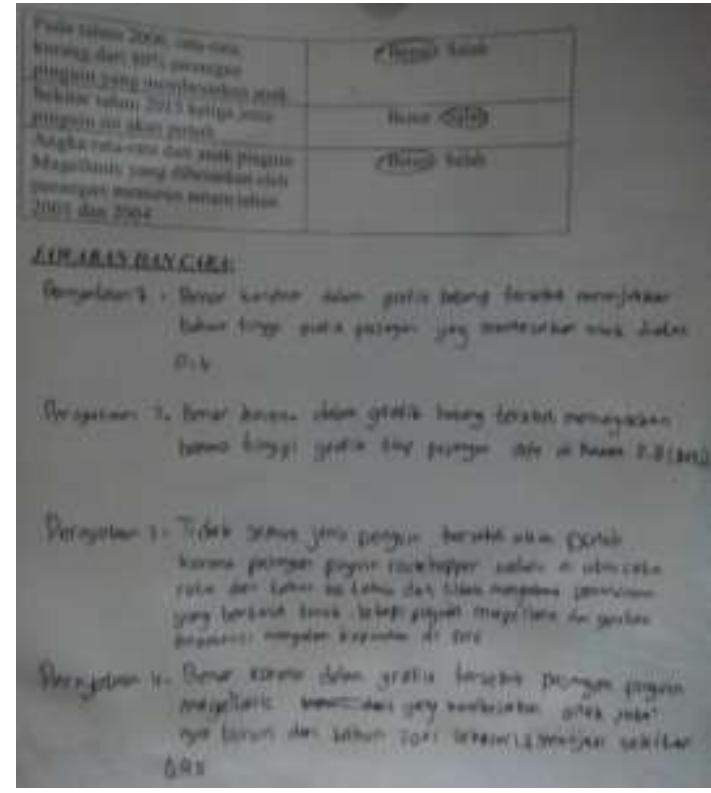

Gambar 18. Hasil pekerjaan nomer 4 subjek PSP

Subjek PSP dalam mengerjakan soal nomer 4 telah menunjukkan langkah pembentukan pengertian. Subjek mengatakan melalui wawancara bahwa informasi yang ia dapatkan berasal dari grafik yang ada didalam soal. Subjek tidak menemukan informasi-informasi serupa maupun yang selalu ada dan mengatakan bahwa seluruh informasi yang ada penting untuk membantu subjek dalam menjawab soal-soal yang ada. Pembentukan pengertian juga dapat dilihat melalui hasil pekerjaan subjek PSP dimana subjek PSP mampu mengabstraksi yaitu dalam mengerjakan soal menggunakan semua pengertian yang ada dan tidak membuang pengertian apapun.

Subjek PSP menunjukkan langkah pembentukan pendapat melalui hasil pekerjaannya dan wawancara. Subjek PSP dalam wawancara mengatakan bahwa ia menghubungkan informasi di dalam grafik untuk membantunya mengerjakan setiap soal yang ada. Langkah pembentukan pendapat subjek PSP dalam soal nomer 4 dapat dilihat melalui hasil pekerjaan subjek PSP dimana dalam memberikan pernyataan benar atau salah menggunakan hubungan-hubungan tiap informasi yang ada.

Kemudian pada langkah pembentukan kesimpulan, subjek PSP menunjukkannya melalui wawancara. Melalui wawancara, subjek PSP mengatakan bahwa kesimpulan yang subjek dapatkan berasal dari hubungan antara pendapatpendapat pada langkah sebelumnya. Kesimpulan yang subjek PSP dapat adalah jawaban soal tersebut dimana jawabannya berturut-turut adalah benar, benar, salah, benar (ditunjukkan pula melalui hasil pekerjaan subjek PSP).

3) Subjek IFP

Hasil pengerjaan soal no 4 oleh subjek IFP adalah sebagai berikut:

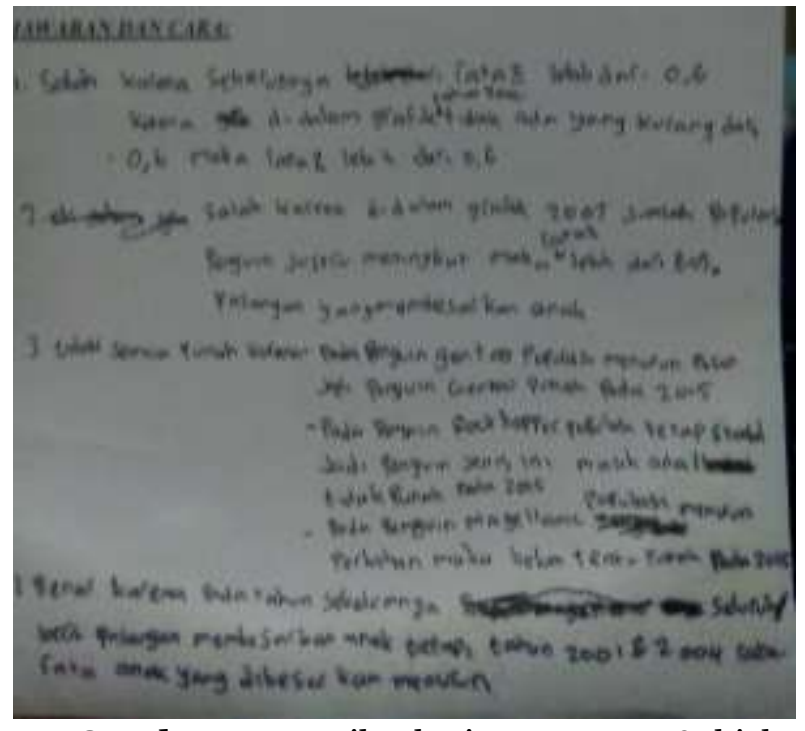

Gambar 19. Hasil pekerjaan nomer 4 Subjek IFP

Subjek IFP dalam mengerjakan soal nomer 4 telah menunjukkan langkah pembentukan pengertian dimana subjek tunjukkan kepada peneliti melalui wawancara dan hasil pekerjaan. Namun, dalam langkah pembentukan pengertian ini subjek mengalami kesulitan, dimana subjek tidak dapat memahami grafik dengan maksimal karena masih belum dapat membaca grafik dengan baik. Subjek IFP mengatakan bahwa tidak semua informasi dapat ia dapatkan dari soal, sehingga beberapa informasi tidak diketahui oleh subjek IFP.

Subjek IFP belum dapat melakukan abstraksi karena subjek tidak mendapatkan semua informasi sehingga tidak mengerti mana yang penting dan tidak untuk diketahui. Namun subjek mengakui bahwa sebenarnya materi tersebut sudah ia dapatkan dalam pembelajaran matematika di kelas, namun karena belum memahami konsep tersebut dengan baik maka subjek INF mengalami kesulitan dalam membentuk pengertian dalam soal tersebut secara lengkap. Seperti terlihat dalam hasil pekerjaan subjek dimana subjek memasukkan informasi secara tidak lengkap dan dalam menjelaskan setiap pernyataan tidak dijelaskan sesuai dengan pengertian yang ada didalam table.

Selanjutnya adalah langkah pembentukan pendapat. Pada langkah pembentukan pendapat, subjek IFP mengalami kesulitan karena kurangnya pengertian yang ia dapat sehingga pendapatpendapat tersebut tidak terbentuk. Subjek mengatakan bahwa dalam mengerjakan soal, subjek menebak-nebak pendapat apa yang dapat membantunya dalam menyelesaikan soal tersebut sehingga subjek IFP tidak yakin bahwa jawabannya benar.

Pada langkah pembentukan kesimpulan, subjek IFP menunjukkannya melalui wawancara dan hasil pekerjaan. Subjek IFP mengatakan bahwa kesimpulan yang ia dapatkan tidak berdasarkan 
pendapat-pendapat karena pendapat yang ia gunakan untuk menjawab adalah hasil menebak dan mengarang. Subjek IFP memberikan kesimpulan akhir berupa jawaban soal yang secara berturut-turut adalah salah, salah, salah, benar.

\section{SIMPULAN DAN SARAN}

Berdasarkan hasil penelitian mengenai deskripsi proses berpikir siswa kelas VIII SMP dapat disimpulkan bahwa ketiga subjek sudah mampu menunjukkan proses berpikirnya. Pada nomer 1 ketiga subjek mampu menunjukkan ketiga langkah proses berpikir baik pembentukan pengertian, pembentukan pendapat, dan pembentukan kesimpulan. Pada nomer 2 ketiga subjek mampu menunjukkan ketiga langkah proses berpikir baik pembentukan pengertian, pembentukan pendapat, dan pembentukan kesimpulan. Pada nomer 3 ketiga subjek mampu menunjukkan ketiga langkah proses berpikir baik pembentukan pengertian, pembentukan pendapat, dan pembentukan kesimpulan. Pada nomer 4 subjek INA dan subjek PSP mampu menunjukkan ketiga langkah proses berpikir baik pembentukan pengertian, pembentukan pendapat, dan pembentukan kesimpulan, namun subjek IFP mengalami kesulitan pada langkah pembentukan pendapat dan pembentukan kesimpulan karena pada langkah pembentukan pengertian tidak di lakukan dengan maksimal (tidak semua pengertian di bentuk oleh subjek).

Peneliti menyarankan kepada guru agar mampu mengetahui proses berpikir siswa karena dengan mengetahuinya guru mampu membantu siswa dalam mengerjakan soal literasi matematika. Pada saat siswa mengalami kesulitan pada langkah tertentu, guru dapat membantu siswa baik dalam membentuk pengertian, membentuk pendapat maupun membentuk kesimpulan. Sehingga dalam mengerjakan soal PISA literasi matematika siswa dapat mengerjakan soal dengan benar dan sistematis.

\section{UCAPAN TERIMA KASIH}

Penulis mengucapkan terima kasih kepada Tuhan Yesus Kristus yang telah memberikan kekuatan dan penyertaan sehingga penulis dapat menyelesaikan TA ini. Penulis berterimakasih pula kepada orang tua, adik dan keluarga tercinta yang tiada habisnya memberikan semangat. Serta kepada sahabat-sahabat dan orangorang tercinta yang selalu menjadi penyemangat dikala lelah.

Terima kasih juga kepada UKSW, FKIP UKSW, dan program studi Pendidikan matematika. Baik para dosen dan mahasiswa yang telah membantu penulis dalam kelancaran pembuatan Tugas Akhir. Penulis juga mengucapkan terima kasih kepada SMP Negeri 1 Salatiga beserta adik-adik subjek atas kerjasamanya dalam memberikan kesempatan kepada penulis untuk melakukan penelitian di institusi hebat tersebut.

\section{DAFTAR RUJUKAN}

[1] Isroil, A., Budayana, I K., and Masriyah, "Profil Berpikir Siswa SMP dalam Menyelesaikan Masalah Matematika Ditinjau dari Kemampuan Matematika”, Jurnal Review Pembelajaran Matematika, vol 2, No. 2, h. 93-105, Desember 2017.

[2] OECD, PISA 2009 Assessment Framework, Paris, OECD Publicing, 2009.

[3] OECD, PISA 2012 Released Mathematics Items, Paris, OECD Publicing, 2013.

[4] OECD, PISA 2015 Draft Mathematics Framework, Paris, OECD Publicing, 2013.

[5] OECD, PISA 2012 Result in Focus, Paris, OECD Publicing, 2014

[6] Santrock, J. W, Psikologi Pendidikan, Salemba Hukum, Jakarta, 2014

[7] Suryabrata, Sumadi, Psikologi Pendidikan, PR Raja Grafindo Persada, Jakarta, 1998.

\section{Biografi Penulis Utama}

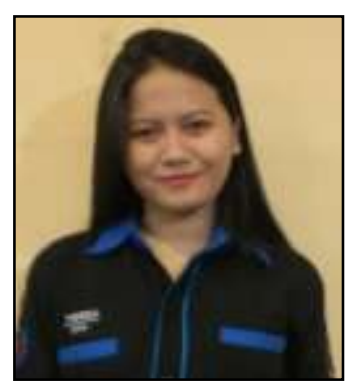

Penulis bernama lengkap Theresia Kartika Candra Dewi. Lahir di Kab. Temanggung pada tanggal 19 Februari 1998 dari pasangan Waldiyanto dan Henni Tri Utami. Penulis adalah anak pertama dari dua bersaudara. Penulis menjalani pendidikan di SD Maria Purworejo pada tahun 2003-2009. Lalu melanjutkan ke SMP N 2 Purworejo pada tahun 2009-2011 dan SMA N 1 Purworejo pada tahun 2011-2014. Selanjutnya melanjutkan pendidikan di perguruan tinggi mengambil jurusan Pendidikan Matematika , Fakultas Keguruan dan Ilmu Pendidikan (FKIP) di Universitas Kristen Satya Wacana pada tahun 2014-2018. Apabila terdapat kritik dan saran dapat dikirim melalui 20204079@student.uksw.edu 